NBER WORKING PAPER SERIES

\title{
WINNERS AND LOSERS FROM ENACTING THE FINANCIAL MODERNIZATION STATUE
}

\author{
Kenneth A. Carow \\ Edward J. Kane \\ Rajesh P. Narayanan \\ Working Paper 11256 \\ http://www.nber.org/papers/w11256
NATIONAL BUREAU OF ECONOMIC RESEARCH 1050 Massachusetts Avenue
Cambridge, MA 02138
March 2005

The authors are grateful to Philip Strahan and James Thomson for valuable comments on an earlier draft. The views expressed herein are those of the author(s) and do not necessarily reflect the views of the National Bureau of Economic Research.

(C)2005 by Kenneth A. Carow, Edward J. Kane, and Rajesh P. Narayanan. All rights reserved. Short sections of text, not to exceed two paragraphs, may be quoted without explicit permission provided that full credit, including (C) notice, is given to the source. 
How Has Financial Modernization Affected Corporate Customers?

Kenneth A. Carow, Edward J. Kane, and Rajesh P. Narayanan

NBER Working Paper No. 11256

March 2005, Revised July 2006

JEL No. G21, G24, G28, L51

\begin{abstract}
$\underline{\text { ABSTRACT }}$
Previous studies of the announcement effects of relaxing administrative and legislative restraints show that signal events leading up to the enactment of the Financial Services Modernization Act (FSMA) increased the prices of several classes of financial-institution stocks. An unsettled question is whether the gains observed for these stocks arise mainly from projected increases in efficiency or from reductions in customer or competitor bargaining power. This paper documents that the value increase came at the expense of customers and competitors. The stock prices of credit-constrained customers declined during FSMA event windows and experienced significant increases in beta in the wake of its enactment. These findings reinforce evidence in the literature on bank mergers that large-bank consolidation is adversely affecting access to credit for capital-constrained firms.
\end{abstract}

Kenneth A. Carow

Indiana University

kcarow@iupui.edu

Edward J. Kane

Department of Finance

Boston College

Chestnut Hill, MA 02458

and NBER

edward.kane@bc.edu

Rajesh P. Narayanan

Ohio University

narayana@ohio.edu 


\section{WINNERS AND LOSERS FROM ENACTING THE FINANCIAL MODERNIZATION STATUTE}

Previous studies of the announcement effects of relaxing administrative and legislative restraints show that signal events leading up to the enactment of the Financial Services Modernization Act (FSMA) increased the prices of several classes of financial-institution stocks. An unsettled question is whether the gains observed for these stocks arise from projected increases in efficiency or from reductions in customer or competitor bargaining power. This paper documents that the value increase came at the expense of customers and competitors. The stock prices of credit-constrained customers declined during FSMA event windows and experienced significant increases in beta in the wake of its enactment. These findings reinforce evidence in the literature on bank mergers that large-bank consolidation is adversely affecting access to credit for capitalconstrained firms.

\section{Introduction}

The Financial Services Modernization Act of 1999 (FSMA) authorized the reciprocal entry of U.S. banks, securities firms, and insurance companies into one another's signature product lines. FSMA repealed Glass-Steagall and Bank Holding Company Act restrictions on financial firms' ability to engage in one another's traditional activities, and also repealed limitations on bank insurance activities imposed by the National Banking Acts of 1864 and $1916 .{ }^{1}$

At the signing of the bill, Treasury Secretary Lawrence Summers predicted that the bill would benefit “American consumers, business and the national economy.” However, given how long the previous regime survived, it is hard to believe that FSMA was truly a win-win proposition for all sectors of the economy. Regulatory adjustments usually generate a distribution of sectoral wins and losses and economic theory suggests that competitors and credit-constrained customers might suffer losses.

Analytically, sectoral wins would register as increased stock values and/or lower risk exposures for constituent firms. Event returns generated by regulatory and legislative steps leading up to the enactment of FSMA indicate that the market anticipated that deregulation would benefit the financial sector. ${ }^{2}$ This paper investigates whether financial organizations might have benefited more than —or even at the expense of —at

\footnotetext{
${ }^{1}$ Also known as the Gramm-Leach-Bliley Act (GLBA), FSMA let stand restrictions set by the Bank Holding Company Act of 1956 (BHCA) on nonfinancial firm entry into banking and on bank expansion into "nonbanking” activities via subsidiary corporations.

${ }^{2}$ Previous event-study findings are summarized in section 4.2
} 
least some customer and competitor sectors. It also asks whether financial-sector benefits from relaxing product-market constraints come merely from projected improvements in efficiency or also from increased bargaining power in dealing with customers and regulators.

Operational and informational scale and scope economies from combining banking, insurance and securities activities within a single organization could simultaneously increase financial-sector profits and lower explicit customer funding costs. Moreover, diversification into new product lines could improve implicit costs by increasing the safety and durability of individual banking organizations and better protect the investments that particular borrowers have made in bank relationships.

On the other hand, product-line extension is apt to increase the size of many banks and to strengthen their competitive position vis-à-vis public credit markets and differently chartered competitors. Increased bank control over firms' access to public and private securities markets could limit access to alternative funding sources for relationship customers, raise their funding costs, and curtail their investment spending. Conglomerate institutions might be tempted to downplay relationship lending and to pass fewer informational quasi-rents through to repeat customers. With fewer competitors vying for a customer's business, resources devoted to analyzing customer-supplied information might fall and relationship customers might confront disadvantageous limit prices or pressure to liquidate collateral. Finally, increases in banking-institution size and complexity could even undermine authorities' ability to prevent securities or insurance risks from spilling onto the federal safety net, harming customers in their capacity as taxpayers.

We conduct statistical tests that show net benefits from FSMA differed for different categories of financial institutions and customers. Some of the gains conveyed to the most favorably situated institutions (insurance companies and commercial banks) came as a transfer from stockholders in customer firms and competing institutions. Within our sample of customer firms, salient events in FSMA's legislative progress produced a 2.53\% cumulative decline in market capitalization. Although very large customers may be said to have gained, credit-constrained customers—defined as younger, smaller firms with single banking relationships, no outstanding public debt and demonstrable financing 
needs - experienced losses. This sector's mean abnormal return cumulates to $-5.22 \%$ over FSMA progress events. The corresponding mean loss for credit-unconstrained customers is only $1.68 \%$. Moreover, for credit-constrained customers, the post-FSMA systematic-risk coefficient (“beta”) rises by 0.20 , while beta declines by 0.30 for the rest of the sample. Cross-sectional regressions explaining individual-firm cumulative abnormal returns confirm that small and credit-constrained customers suffered significant harm.

To translate sample results into estimates of aggregate gains and losses for financial and nonfinancial firms, we make a heroic assumption. This assumption is that median gain and loss rates experienced by sample firms would be representative of the medians for corresponding size classes used by the Census Bureau to report the size distribution of receipts at public and private firms. On this assumption, calculations reproduced as an Appendix show that nonfinancial firms lost nine times as much from FSMA (\$467 billion) as financial firms gained (\$52 billion). Even if other estimation strategies could reduce this ratio substantially, the size of the implied deadweight loss indicates that proponents greatly overstated the efficiency benefits of FSMA.

Our findings reinforce anecdotal concerns expressed in the business press ${ }^{3}$ and econometric evidence in the bank merger literature that ongoing consolidation in the banking industry is adversely affecting the ability of small firms to finance their growth opportunities.

The rest of the paper is organized as follows. Section 2 discusses the potential impact of financial modernization on customer welfare and derives testable hypotheses. The paper's statistical methods are described in section 3. Section 4 presents and interprets our findings. The final section summarizes our empirical results and relates them to other event studies of financial deregulation and banking consolidation.

\footnotetext{
${ }^{3}$ A sampling of complaints expressed in response to the Fleet-BankBoston merger is assembled in Frieswick (2004): “the merged bank doesn't give you the total borrowing capacity that you used to have.” (Steven Wasserman, CFO of Symantec Corporation); "Banking is about relationships...If there's a reduction in quality of service and our relationship team gets cut that could be a deal breaker." (Regina Sommer, CFO of Netegrity); "fewer available bank officers is less daunting to FleetBoston corporate customers that have diversified their bank relationships to prevent just such overdependence.” (Lee Kidder, director of wholesale-banking research at TowerGroup, and former head of commercial-loan operations at BankBoston). Kidder also warns that future megabanks may have the bargaining power to increase fees and rates, change credit terms and corporate lending relationships, or choose not to renew a line of credit.
} 


\section{Financial modernization and customer welfare}

Modern banking theory assigns banks a special role in information production and monitoring. The many points of contact a bank has with its repeat customers generate private information and mutual trust. Diamond's delegated-monitoring hypothesis envisions that banks either win access to inside information from repeat customers or uncover such information in the course of supporting and observing these customers' loan and deposit business (Diamond, 1984).

Privileged information allows a bank to assess and to price the risk of lending to a relationship customer more accurately than the bank's competitors can price risk. For this reason, close ties with banks are valuable to healthy firms. ${ }^{4}$ In principle, abilities or capacities that create extra-normal rents are intangible assets. Their value can be expressed as a mutual claim to the capitalized flow (R) of reduced opportunity costs. The outcome of a bilateral bargaining process (BP) allocates R partly to the relationship customer $\left(\mathrm{R}_{\mathrm{C}}\right)$ and partly to the bank $\left(\mathrm{R}_{\mathrm{B}}\right)$ (Kane and Malkiel, 1965)

$$
\mathrm{R}(\mathrm{BP})=\mathrm{R}_{\mathrm{C}}(\mathrm{BP})+\mathrm{R}_{\mathrm{B}}(\mathrm{BP}) .
$$

Changes in a customer's $\mathrm{R}_{\mathrm{C}}$ can come either from changes in $\mathrm{R}$ or from changes in the balance of bargaining power. Product-line extension can benefit customers by displacing high-cost specialized firms (Jayaratne and Strahan, 1998 ) and by widening and lengthening the contact a bank has with its relationship customers. Cross-selling opportunities can uncover new information, improve monitoring capabilities, and decrease agency costs, while expanding opportunities to use privileged information might unlock scale and scope economies in various service capacities. Prior to FSMA, banks were allowed to establish separately incorporated security affiliates on a case-by-case basis (Section 20 banks and affiliates). Suggesting the possibility of scope economies, Gande, Puri, and Saunders (1999) and Roten and Mullineaux (2002) find that debt

\footnotetext{
${ }^{4}$ Numerous studies confirm that banking relationships are valuable to firms. James and Smith (2000) survey studies that proxy the value of banking relationships by borrower stock-price response to originations or renewals of credit facilities. Petersen and Rajan (1994) and Berger and Udell (1995) are excellent examples of studies of how enhanced credit availability and lower funding costs correlate with close lending ties to banks.

${ }^{5}$ Because $\mathrm{R}$ requires the cooperation of both parties in that they want to avoid outcomes that would eliminate the counterparty's incentive to renew the relationship, equilibrium $R_{C}$ and $R_{B}$ should each be strictly positive.
} 
underwritten by bank affiliates carried lower underwriting fees than comparable issues underwritten by investment banks.

On the other hand, product-line expansion also increases asset size. Well-known "size effects" in lending predict that the formation of larger, more complex banking institutions might adversely affect small customers. Berger, Miller, Petersen, Rajan and Stein (2005) show that small banks are more likely than large banks to extend loans to borrowers that lack formal records. They also find that small-bank lending travels over shorter distances, capturing localized knowledge of borrower condition. Evidence reviewed by Berger, Demsetz and Strahan (1999) shows that a threshold asset size exists at which banks begin to channel an increasing proportion of their lending to large firms. Stein (2002) and Berger and Udell (2002) attribute this phenomenon to bureaucratic blockages in the movement of customer information across components of large and complex banks. These blockages result in the use of different technologies for lending to large and small firms. Both papers portray large banking organizations as favoring transaction-based loans to large firms over relationship loans to smaller ones. Stein (2002) emphasizes that line managers' incentives to research a given customer decline with increases in bank size and complexity because soft information becomes harder to communicate across the bank. Berger and Udell (2002) argue that monitoring difficulties at large institutions tempt relationship managers to overinvest in generating new loans and to hide evidence of deterioration in existing loans.

Studies of merger events seldom find potential benefits for bank customers. Scale economies in lending appear to exist only at very small banks. Moreover, only when markets are competitive are merger benefits shifted to small customers. In the United States, Strahan and Weston (1998) and Berger, Saunders, Scalise and Udell (1998) find small-business lending increases in mergers involving small banks, but decreases when large banks combine. Ely and Robinson (2004) show that large banks with security affiliates show significantly smaller proportions of small-business loans than similar banks that have no security affiliate. Carow, Kane and Narayanan (2004) find that the megamergers in the U.S. lower the stock prices of small, credit-constrained customers. Studies of bank mergers in Norway and Italy uncover similar effects. Karceski, Ongena and Smith (2005) find that bank merger announcements reduce the equity value of small 
publicly traded Norwegian firms that are customers of the bank being absorbed, with the extent of the decline increasing with the size of the target. In Italian bank mergers, Sapienza (2002) finds contract interest rates on bank loans decline when banks with small market shares combine, but increase in more-substantive mergers.

Apart from size-related lending patterns, small customers could be harmed by shrinkage in the number of outlets competing for their funding business. Diamond (1993) argues that firms that have few funding outlets face a threat of inefficient liquidation. The danger is that, when a firm runs short of tangible capital, its creditors may ignore intangible going-concern values in deciding between rolling over short-term loans and liquidating its collateral. Houston and James (1996), Detragiache, Garella and Guiso (2000) and Degryse and Ongena (2004) establish that firms which already have public debt outstanding or have multiple banking relationships are less susceptible to hold-up pressure. However, benefits from access to public debt may be swamped if, as Drucker and Puri (2005) suggest, banks can link the availability of loans to customers' use of its investment-banking services. Kanatas and Qi (2003) show that bank information monopolies increase the cost to a relationship customer of using an unrelated investment bank for public capital. By increasing bargaining power, reduced competitive pressure could enable a bank to reduce $\mathrm{R}_{\mathrm{C}}$ : the value of informational quasi-rents the market shifts forward to relationship customers. Customers could lose bargaining power in two ways. First, a customer that seeks funds from the capital market faces a cost from not using its relationship bank as its investment banker in the form of a "lemon's discount." This discount reflects the market's fear that the relationship bank might have found the customer uncreditworthy. Second, a bank’s information advantage in predicting the timing of customer funding activity may generate limit-pricing opportunities. Empirical studies confirm the importance of these effects. Yasuda (2005) and Ljungqvist, Marston and Wilhelm (2005) find that lending banks disproportionately capture the underwriting business of relationship customers. Consistent with these studies, we find that, ceteris paribus, having public debt outstanding reduced abnormal returns from FSMA progress events.

Political clout tends to increase whenever a bank attains or solidifies its megabank status. On the one hand, increased clout reduces the chance of failure. Many studies 
confirm the value of bank durability to customers. Looking at the 1984 collapse and subsequent rescue of Continental Illinois Bank, Slovin, Sushka and Polonchek (1993) show that customers' wealth rises and falls with fluctuations in their lending institution's financial health. Kang and Stulz (2000), Bae, Kang and Lim (2002), and Ongena, Smith and Michalsen (2003) show that adverse shocks to national banking systems reduced borrower stock prices in Japan, Korea and Norway, respectively. On the other hand, by reducing the effectiveness of regulatory discipline, increased bank clout can hurt customers. Kane (2000) argues that in bank megamergers some of the stock price increases experienced by targets and acquirers come from becoming increasingly "Too Big to Discipline Adequately.” This contention is reinforced by Penas and Unal's finding (2004) that the yields on the outstanding bonds of acquiring and target megabanks both decline.

The net effect of FSMA on any individual customer depends on whether the passthrough of regulatory subsidies and scope economies generated by growth in bank size and product lines outweighs losses from reductions in the customer's bargaining power. It is reasonable to hypothesize that, except for very large customers, FSMA might have strengthened the relative bargaining power of banks. Credit-constrained firms - defined as younger, smaller corporations with a single banking relationship, no outstanding public debt and demonstrable financing needs-seem especially vulnerable to changes in the balance of bargaining power. As a bank increases in size and scope, it might prefer to charge higher rates to such customers or to finance fewer of their growth opportunities. In this case, as the FSMA advanced through the enactment process, concern about the ability of credit-constrained firms to finance positive present-value projects would reduce their stock prices and fears of adverse movements in their cost of capital and ability to control essential collateral might raise their beta.

\section{Methods}

Event-study methods are an established way to measure the welfare effects of 
legislation. ${ }^{6}$ Schwert (1981) roots the method's evidential value in the strong likelihood that markets are at least weak-form efficient. If stock prices incorporate relevant information as it becomes publicly available, observed changes in stock prices estimate changes in wealth and risk exposures occasioned by particular events.

Wealth effects from "legislative progress" are identified with statistically significant deflections from a benchmark trajectory for expected returns on portfolios of stocks in selected sectors and subsectors. Inferences about risk focus on changes in portfolio betas between pre-enactment and post-enactment periods.

A legislative-progress event study begins by designating salient dates at which information might have been transmitted to the market. Next, stakeholder groups ("sectors") must be identified, and portfolios representative of these groups constructed. Finally, a model of pre-event "expected" returns on these portfolios must be developed to benchmark "normal” returns for each portfolio on the event days. How this paper proceeds through these steps is described in the next three subsections.

\subsection{Legislative progress events}

Prior to the FSMA, banks devised clever ways to cross industry borders and regulators subsequently redrew the borders to legitimize most incursions. Because circumventive entry incurs continuing avoidance costs, even banking organizations that had successfully smuggled themselves across the borders could benefit from legitimizing or widening loopholes.

Over time, financial institutions’ demand for new powers grew and regulatory agencies became increasingly willing to use their rule-making powers to relax statutory burdens. For example, in the mid-1980s, the Federal Reserve Board authorized bank holding companies (BHCs) to establish "Section 20" subsidiaries that could underwrite previously "bank ineligible” securities activities merely by staying within evolving percentage-of-revenue and interaffiliate limits. On the insurance front, several state regulators (e.g., in South Dakota in 1983 and Delaware in 1990) permitted state-chartered banks (including institutions owned by out-of-state holding companies) to sell insurance

\footnotetext{
${ }^{6}$ Binder (1997) surveys the use of event-study methods to assess welfare effects from changes in regulatory regimes.
} 
products nationwide. FSMA firmed up and equalized financial institutions’ rights to exercise banking, securities, and insurance powers within a single organization.

Event-window movements in stock prices are particularly informative when events surprise market participants. The prior interplay of arbitrage-like circumvention and regulatory or statutory realignment of charter powers lessened the competitive impact of FSMA and the value of the information that legislative-progress events could convey.

Prior to 1999, 12 Congresses repelled 12 attempts to pass similar legislation. On May 6, 1999, financial-modernization legislation advanced beyond the committee level for the first time, winning approval in the Senate. Our event timeline starts at this date and progresses to enactment six months later. On July 1, the House of Representatives approved its own version of the bill. A joint congressional committee formed to reconcile the two versions announced significant progress on October 13, although issues of regulatory jurisdiction remained unsettled. On October 15, the Federal Reserve and the Treasury announced that they had settled their jurisdictional issues. A final obstacle was White House insistence that the Community Reinvestment Act (CRA) not be undermined. A compromise between the White House and the House and Senate conferees surfaced on October 22 and a final conference report was issued on November 2. Both chambers passed the bill on November 4 and President Clinton signed the Financial Services Modernization Act into law on November 12. Table 1 lists and dates these legislative-progress events. ${ }^{7}$

\subsection{The Sampling Frame}

Our study samples two broad stakeholder groups: financial firms and their corporate customers. The Center for Research in Security Prices database (CRSP) contains 682 financial-services firms. We partition these firms into seven subsectors: 268 U.S. banks (3-digit SIC code 602 but excluding the 4-digit SIC code 6029 and section 20 banks), 25 Section 20 banks, 194 thrifts (3-digit SIC 603), 33 finance companies (3-digit SIC 61), 45 investment banks (3-digit SIC 62), 95 insurance companies, and 22 insurance agencies (3-digit SIC 641).

\footnotetext{
${ }^{7}$ Information-generating event dates were identified using the Wall Street Journal Index, New York Times Index, Congressional Quarterly Weekly Report, and prior studies of FSMA.
} 
Our sample of current and prospective customers is drawn from the universe of nonfinancial corporations. To be included in our study, a firm had to meet four dataavailability criteria:

1. be traded on either the NYSE, AMEX, or NASDAQ,

2. have daily returns available on CRSP during 1999,

3. be traded on at least $70 \%$ of the possible trading days, and

4. have balance-sheet and income-statement data on Compustat.

Applying the first three data requirements to the CRSP dataset produced 6803 firms. The Compustat data requirement reduced the number of firms to 3820. Separating out firms whose SIC code (=6) classifies them as financial companies, and eliminating outliers (firms whose event-day return exceeds 15\% in absolute value) narrowed the sample to 3008 customers.

To represent the competitiveness of each customer's funding environment we construct the following measures for each customer: ${ }^{8}$

EFN: External Financing Needs, defined as planned investment minus internally generated funding.

PUB_DEBT: an indicator variable that takes on the value one if the firm has public bonds outstanding; and is zero otherwise.

AGE: Log of number of years that the firm's stock has been trading publicly.

SIZE: Log of asset size (in \$million).

MUL_REL: an indicator variable that equals one for customers that have multiple banking relationships; and is zero otherwise.

SECTION20: an indicator variable that equals one for customers of a bank with a section 20 underwriting affiliate; and is zero otherwise.

Rajan and Zingales (1998) and Cetorelli and Gambera (2001) demonstrate that the growth of firms in need of external finance depends on the developmental state and industrial structure of the financial environment in which firms seeks capital. Strahan and Weston (1998), Berger et al (1998), Karceski, Ongena, and Smith (2004) and Sapienza (2002) find that firm size is among the best proxies for customer bargaining power. Kanatas and Qi (2003) identify age as a factor. Houston and James (1996) and

\footnotetext{
${ }^{8}$ The Appendix describes in a reproducible way how these variables are constructed.
} 
Detragiache, Garella, and Guison (2000) show that multiple relationships and the presence of public debt mitigate adverse selection and hold-up costs. Consistent with these studies, we define a customer as potentially "credit-constrained" (denoted by a CREDIT_CONSTRAINED indicator) when it lies in the less-favorable tail of the distribution of each of these five variables. CREDIT_CONSTRAINED equals one when:

$$
\begin{aligned}
& \text { EFN }>0 \text {, } \\
& \text { PUB_DEBT }=0 \text {, } \\
& \text { AGE }=10 \text { years or less, } \\
& \text { SIZE }<\text { log of } \$ 500 \text { Million, } \\
& \text { MUL_REL }=0 \text {; and is } 0 \text { otherwise. }
\end{aligned}
$$

This definition yields 722 credit constrained-customers and 2286 credit-unconstrained peers.

\subsection{Model}

To estimate event returns, we employ the multivariate regression model (MVRM). The MVRM model employs Zellner's (1962) seemingly unrelated regression framework. It specifies a simultaneous system of market models (one for each sectoral portfolio), explicitly conditioned on the occurrence (nonoccurrence) of the event. This model corrects for heteroskedasticity and for contemporaneous dependence of individualequation errors. This allows us to test differences in sectoral responses to an event as well as to overcome problems associated with event-day clustering. ${ }^{9}$

The MVRM takes the form:

$$
r_{j t}=\alpha_{j}+\beta_{j} r_{m t}+\sum_{k=1}^{n} \gamma_{j k} D_{k}+\varepsilon_{j t}
$$

Parameters and variables are defined as follows:

$r_{j t}=$ the return for portfolio $\mathrm{j}$, on day $\mathrm{t}$;

\footnotetext{
${ }^{9}$ For a more detailed explanation of the MVRM and of its advantages in testing the impact of regulatory events, see Binder (1985a and 1985b).
} 
$\alpha_{j}=$ the value of the intercept for portfolio $\mathrm{j}$;

$\beta_{j}=$ the systematic risk of portfolio $\mathrm{j}$;

$r_{m t}=$ the market return on day $\mathrm{t}$;

$\gamma_{j k}=$ the event-induced shift in the intercept (i.e., the abnormal return) generated by event k;

$D_{k}=$ a dummy variable that takes on the value of 1 during the two-day event window for event $\mathrm{k}$, but is zero otherwise; $\varepsilon_{j t}=$ the error term for portfolio j on day t.

The return on each portfolio $\mathrm{j}$ is constructed by weighting the returns of constituent firms equally. The equally weighted CRSP market index serves as the market proxy. Returns are observed during a 10 1/2-month period running from January 1, 1999 to November 15, 1999. This “event period” encompasses eight specific progress events.

Event dummies $\left(D_{k}, k=1, \ldots, 8\right)$ deviate from zero on the $k^{\text {th }}$ event date and on the day following the event. A two-day event window is selected to account for the diffusion of information following the event date. The coefficient of each $D_{k}\left(\gamma_{j k}\right)$ expresses the abnormal return on portfolio j generated by event $\mathrm{k}$. Net sectoral benefits derived from the Act are measured by the cumulative abnormal return (CAR) which sums the $\gamma_{j}$ responses over all eight events.

For the legislative-progress period as a whole, we first test whether CARs differ among the sectoral portfolios. Rejecting the null hypothesis would confirm that financial modernization impacted individual-sector portfolios differently. We also test the significance of the sum of CARs across the sectoral portfolios. Our inability to reject the null hypothesis would indicate that, contrary to the Treasury Secretary's claim, sectoral gains and losses generated by the event might be redistributive in nature, neither creating nor destroying wealth in the aggregate.

Changes in a customer's shadow price for external funding might also increase the riskiness of its future earnings. To test this hypothesis, we investigate whether FSMA 
also affected customer betas. This requires that we expand the model to include periodspecific slope and intercept dummies. The expanded model takes the form:

$$
r_{j t}=\alpha_{j}+\beta_{j} r_{m t}+\sum_{k=1}^{n} \gamma_{j k} D_{k}+\alpha_{j}^{\prime} D_{E V E N T}+\beta_{j}^{\prime} r_{m t} D_{E V E N T}+\alpha_{j}^{\prime \prime} D_{P O S T}+\beta_{j}^{\prime \prime} r_{m t} D_{P O S T}+\varepsilon_{j t} .
$$

In (3),

$D_{E V E N T}=$ a dummy variable assigned the value of 1 in the event period — from January 1 , 1999 to November 15, 1999; and is zero otherwise.

$D_{\text {POST }}=$ a binary variable that takes the value of 1 in the post-event period-from

November 16, 1999 to May 15, 2000; and is zero otherwise.

Model (3) is estimated over the period July 1, 1998 to May 15, 2000. ${ }^{10}$ The specification expresses systematic risk in the event period as the sum of $\beta_{j}+\beta_{j}^{\prime}$, in the post-event period as $\beta_{j}+\beta_{j}^{\prime \prime}$, and the variable BETACHANGE $\mathrm{j}_{\mathrm{j}}$ as $\beta_{j}^{\prime \prime}$.

\subsection{Cross-sectional tests}

Whether due to projected changes in relationship value $(\mathrm{R})$ or in bargaining power (BP), cumulated abnormal returns (CAR) express the net impact of FSMA on customerrelationship value $\left(R_{C}\right)$. To investigate whether this net effect is significant, we undertake a second round of testing. This round treats individual-customer $\mathrm{CAR}_{\mathrm{i}}$ and BETACHANGE $E_{\mathrm{i}}$ as joint proxies for relationship value $\left(\mathrm{R}_{\mathrm{i}}\right)$ and bargaining power $\left(\mathrm{BP}_{\mathrm{i}}\right)$. Individual-firm $\mathrm{CAR}_{\mathrm{i}}$ and $\mathrm{BETACHANGE}_{\mathrm{i}}$ are generated in the MVRM regressions as parameter estimates for sectoral portfolios.

Second-round regressions seek to approximate the following latent model:

$$
\text { CAR }_{\mathrm{i}}(\text { or BETACHANGE })=\mathrm{a}_{\mathrm{i}}+\mathrm{b}_{\mathrm{i}} \mathrm{R}_{\mathrm{i}}+\mathrm{c}_{\mathrm{i}} \mathrm{BP}_{\mathrm{i}}+\mathrm{u}_{\mathrm{i}} \text {. }
$$

In estimating (4), the joint influence of $\mathrm{R}_{\mathrm{i}}$ and $\mathrm{BP}_{\mathrm{i}}$ is proxied by variables that represent the intensity of the competitive and informational environment in which the customer

\footnotetext{
${ }^{10}$ Introducing 6-month intervals on both sides of January 1, 1999 - November 15, 1999 lets us estimate shifts in beta and allows us to make inferences about the influence of legislative-progress events on stockprice volatility.
} 
must negotiate loan financing. Parameter estimates presented in our tables are for equation (5):

$$
\begin{aligned}
\text { CAR } \left._{\mathrm{i}} \text { (or BETACHANGE }\right)= & \mathrm{a}_{\mathrm{i}}+\mathrm{b}_{1} \text { SECTION20 }_{\mathrm{i}}+\mathrm{b}_{2} \text { EFN }_{\mathrm{i}}+\mathrm{b}_{3} \mathrm{SIZE}_{\mathrm{i}}+\mathrm{b}_{4} \text { PUB_DEBT }_{\mathrm{i}} \\
& +\mathrm{b}_{5} \text { MUL_REL }_{\mathrm{i}}+\mathrm{b}_{6} \mathrm{AGE}_{\mathrm{i}}+ \\
& \mathrm{b}_{7} \text { CREDIT_CONSTRAINED }_{\mathrm{i}}+\mathrm{u}_{\mathrm{i}}
\end{aligned}
$$

\section{Results}

\subsection{Sectoral tests}

We begin by estimating the MVRM model parsimoniously for two consolidated sectors: financial firms and corporate customers. Table 2 presents the results. Panel A shows that the average financial institution gained $1.20 \%$ in market value over the legislative progress period, but this value does not differ significantly from zero. Still, because $57.48 \%$ of the firms in the financial-sector portfolio experience positive abnormal returns, we can reject (at the 1\% level) the null hypothesis that abnormal returns are evenly divided between positive and negative values. Explaining some of the benefits experienced by financial institutions, the average customer lost $2.53 \%$ of its market capitalization. Only $43.35 \%$ of the customer sample shows a positive CAR. A sign rank test confirms that this percentage differs significantly from 50\%. To assess the economic significance of these findings, we multiply each firm's market capitalization at the start of the legislative period by its CAR and aggregate across the sector. Over the eight progress events, the financial sector registers a $\$ 74$ billion or 3.62\% gain on its May 5, 1999's market capitalization of \$2.04 trillion. These returns show that large financial firms gained more at the passage of FSMA than their smaller counterparts. The corresponding numbers for the customer sector are a $\$ 407.2$ billion decline and a $-4.16 \%$ loss on an initial capitalization of $\$ 9.76$ trillion.

Panel B shows that both sectors experience significant declines in systematic risk. For the financial-sector portfolio, beta declines from 0.90 to 0.37 in the post-event period. This decline is significant at the $1 \%$ level. Only $11.29 \%$ of the financial firms show an increase in beta. This firmly rejects the hypothesis that, within the financial sector, beta 
changes are evenly divided. ${ }^{11}$ The customer portfolio shows a smaller decline in beta, from 1.10 to 0.91 . However, even this smaller decline is significant at $1 \%$ because only $30.49 \%$ of the firms experience an upward revision.

Results in panel C confirm that event returns experienced by financial institutions differ significantly from customer returns. Both the F-test and the Wilcoxon rank sum test reject the null hypothesis that event returns are the same for both sectors. While efficiency gains may exist, an F-test fails to reject the hypothesis that event returns across these consolidated sectors sum to zero. This indicates that at least some of the institutions’ gains are redistributive. In the aggregate, financial institutions fared better than their customers.

\subsection{Intrasectoral tests}

To investigate wealth effects within each of the consolidated sectors, we estimate MVRM models for nine subsector portfolios: seven financial-industry subsectors and two customer subsectors. The financial subsectors are: finance companies, insurance agencies, thrifts, insurance companies, investment banks, all commercial banks, and commercial banks with section 20 security-underwriting affiliates. The customer subsectors distinguish credit-constrained and credit-unconstrained firms.

Table 3 disaggregates the financial sector. Insurance companies, investment banks, and commercial banks (the highlighted area of the table) gain value, while insurance agencies, finance companies and thrifts lose value. Similar results are documented by Akhigbe and Whyte (2001), Carow and Heron (2002), Hendershott, Lee, and Tompkins (2002), and Yu (2002). The easiest way to explain this intrasectoral wealth redistribution is to attribute it to expanded opportunities for industry consolidation opened up by FSMA. Investors apparently expected large multiproduct financial institutions to improve their competitive position relative to more-specialized industry participants.

Table 4 disaggregates the customer subsector. Both subsectors lose market capitalization, but credit-constrained customers suffer more severely (-5.22\%) than unconstrained firms (-1.68\%). Moreover credit-constrained customers experience an

${ }^{11}$ Using a similar estimation period, the reduction in systematic risk for each of the financials sectors is also documented in Akhigbe and Whyte (2004). 
increase in beta from 1.32 in the pre-event period to 1.52 in the post-event period, while the unconstrained firms experience a decline in beta from 1.03 to 0.73 over the same time period. Parametric and nonparametric tests confirm that the wealth loss for creditconstrained customers is significantly greater than for unconstrained customers.

Tables 3 and 4 suggest that, although some of the benefits achieved by commercial banks, securities firms and insurance companies trace to opportunities to outcompete other financial sectors, additional gains came at customer expense and especially from small, credit-constrained firms.

\subsection{Cross-sectional results}

Table 5 treats CAR and beta change as endogenous variables for individual firms. In the CAR regression (I), SIZE and the negative effect of CREDIT_CONSTRAINED prove significant at the $1 \%$ level. Other things equal, average stock-price revisions are less negative for larger firms and more negative for credit-constrained ones. This is predicted by the hypothesis that a customer's bargaining power increases with its size and decreases with funding constraints. However, the negative sign found for PUB_DEBT supports the hypothesis that some of the continuing investment-banking business of relationship customers is apt to be disadvantageously forced into the bank.

In the BETACHANGE regression (II), many more variables prove significant. Size and credit-constrained variables remain significant, but (as hypothesized) their signs reverse. The EFN coefficient is positive and significant. In combination with the positive sign accorded PUB_DEBT, this further supports the hypothesis that funding costs and effective access deteriorate. As in the CAR equation, increases in size can overcome adverse effects. Given the correlation known to exist between the sizes of banks and their customers, the negative and significant coefficient for the SECTION20 dummy (-0.17) reinforces the effects of size in reducing risk at the relatively large firms that are customers of the generally large Section 20 banks. The significantly positive coefficient for AGE (0.04) shows that, at the margin, increases in firm age can only slightly improve a customer's bargaining power.

Tables 4 and 5 demonstrate that the stock prices of credit-constrained customers declined during FSMA event windows and that credit-constrained customers experienced 
significant increases in systematic risk in the wake of its enactment. These findings reinforce evidence in the literature on bank mergers that large-bank consolidation is unfavorably affecting the price and/or availability of credit for capital-constrained firms.

\subsection{Robustness Experiments}

Tables 6, 7, and 8 explore the sensitivity of our results to variation in sampling technique, variable definitions, and model specification. The qualitative implications of the results shown in Table 5 remain unchanged.

Sampling Current Customers Only. Tables 2, 4, and 5 analyze a sample drawn from the universe of current and prospective customers. The first columns of Tables 6 and 7 report results from sampling from the universe of current customers only.

The first column of Table 6 shows that, although slightly stronger in magnitude, the values of significant effects on customer CARs are much the same in the restricted sample. However, the first column of Table 7 shows that the usefulness of the betachange regression virtually disintegrates. Only SIZE remains strongly significant and, like $\mathrm{R}^{2}$ and the other previously significant variables, its value is greatly reduced. Taken together, these experiments indicate that established bank customers are expected to be financed more reliably and slightly more cheaply than potential customers.

Using Loan Pricing Corporation's (LPC) Dealscan database, we identify firms that have an active loan facility with a sample bank that is designated to be either a sole lender or a lead lender in a syndicate during the period January 1, 1999 to November 15, 1999. ${ }^{12}$ As described by Angzabo, Mei and Saunders (1998), an originating institution is a lead lender in a syndicate if it retains primary administrative, monitoring and contractenforcement responsibilities along with (typically) the largest stake in the loan. Other institutions in the syndicate are either managers or participants. Managers usually perform minor administrative duties and hold much smaller stakes in the loan than lead lenders. Participants function only as signatories to the loan agreement and entities that fund a piece of the loan. According to Yasuda (2005) “lending relationships” are highly

\footnotetext{
${ }^{12}$ The Loan Pricing Corporation’s (LPC) Dealscan database provides details of loans over $\$ 100,000$ compiled from 13Ds, 14Ds, 13Es, 10Ks, 10Qs, 8Ks, and S-series (registration) statements that publicly held companies and privately held companies with public debt outstanding file with the Securities Exchange Commission.
} 
correlated with the hierarchy of shareholdings in the syndicate: lead lenders are typically relationship banks; participants are merely invited to help fund the loan by the lead lenders; and managers stand somewhere in between.

Identifying lead lenders by titles such as arranger, co-arranger, administrative agent, agent or co-agent, and imposing the data requirements specified earlier, yields a sample of 1218 nonfinancial customers. This subsample of relationship customers omits weaker and developing relationships. While imposing these restrictions has the obvious advantage of identifying established relationship customers, it has the disadvantage of increasing the proportion of large firms (already an issue in sampling from the Dealscan universe) and reducing the number of credit-constrained customers. ${ }^{13}$ Although results from either sample remain qualitatively similar, the restricted sampling strategy reduces the power of tests of the hypothesis that small, credit-constrained firms suffer disproportionately from the enactment of FSMA.

Alternative Specifications. Industry type might affect both the character of a firm's credit needs and the availability of assets that can serve as collateral. Although $\mathrm{R}^{2}$ improves, we find no qualitative differences from our benchmark results when we control in Tables 6 or 7 for industry type with either one or two-digit SIC indicators. The last column of each table introduces four other control variables: Tobin's Q, the debt-to-asset ratio, and indicators for dividends and for research \& development expense. Although each of these further controls is significant in one equation or the other, the signs of all coefficients that proved significant in Table 5 remain the same. In only one case (namely, for PUB_DEBT in the CAR equation) does any coefficient become insignificant. Finally, although not reported here, the pattern of significant results proves much the same when we use value-weighted market returns instead of equally-weighted market returns to calibrate abnormal returns and betas.

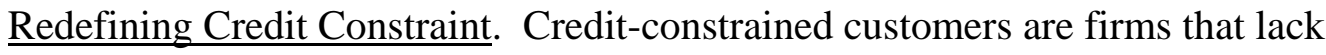
internal resources for financing planned investment expenditures and promise as well to have difficulty meeting their need for external funding. Our indicator for credit

\footnotetext{
${ }^{13}$ The number of credit-constrained customers in the restricted sample of 1218 "LPC" customers is 168 (or 13.8\%). This compares to 722 (or $24.0 \%$ ) credit-constrained customers in the primary sample of 3008 firms.
} 
constraint combines the impact of facing a funding gap with four measures of the potential narrowness of the firm's funding environment.

The literature offers two alternative strategies for classifying firms as financially constrained. The first strategy is to look for a single characteristic that might signal financing constraint. Particular characteristics that others have used to classify a firm as financially constrained include: small size [Gertler and Gilchrist (1993)]; the absence of a bond rating [Kashyap, Lamont and Stein (1994)]; and dividend distributions [Fazzari, Hubbard and Petersen (1998)].

The second approach combines several firm characteristics into an endogenous classification model: for example, conditioning the retention ratio on Tobin's $Q$ as in Korajczyk and Levy (2003) or constructing indices as in Kaplan and Zingales (1997) and Whited and Wu (2005). Size and the presence of public debt (and hence a bond rating) already appear in our regressions.

Korajczyk and Levy's (2003) classification scheme embodies the idea that since dividends and security repurchases compete for funds with investments, firms with attractive investment opportunities and high agency costs for external finance may be expected to retain net income for investment purposes. Conditioning on Tobin's Q helps to ensure that resource-constrained firms have meaningful investment opportunities and are not financially distressed. Applied to our sample, Korajczyk and Levy’s measure of financial constraint classifies 901 firms as financially constrained. Table 8 shows that these firms experience larger negative abnormal returns and larger positive beta changes than firms classified as unconstrained. Introducing the KL measure along with CREDITCONSTRAINED into the abnormal-return and beta-change regressions increases our model's explanatory power, but does not render CREDIT-CONSTRAINED insignificant.

Whited and $\mathrm{Wu}$ (2005) use GMM to estimate an intertemporal model of investment and financial frictions that correlates better with CREDIT-CONSTRAINED than with the other two indices. Whited and $\mathrm{Wu}$ interpret their index as a shadow price for external finance to which every firm must adjust in equilibrium. They show that their index meets the test of being a priced factor in a Fama-French model. When we restrict our sample to the 2210 firms that report the data needed to construct Whited and Wu's measure or the 2199 firms that report data needed to construct Kaplan and Zingales’ measure, credit- 
constrained firms continue to show significantly lower FSMA event returns and significantly higher post-FSMA systematic risk.

\section{Summary and implications}

Previous investigations of event returns associated with the FSMA and piecemeal loophole expansions show stock-price benefits for banks, investment banks, and insurance companies. Such gains are strongly predicted by partial-equilibrium analysis. The intensity of prior lobbying activity shows that at least some of the abandoned constraints on product offerings had inefficiently limited institutions' ability to use their private information, contracting skills, and scope economies. Removing these binding constraints should permit affected institutions to exploit private information on clients to design, market, and price their product lines more effectively than before. In general equilibrium, however, the benefits that favored financial institutions win from exercising their new freedoms must be weighed against losses that might develop elsewhere in the economy.

Given how stubbornly Congress resisted previous efforts to repeal product-line restrictions, it is clear that important sectors had an economic stake in their continuance. Economic theory indicates that expanding the scope of institutional charters might expand opportunities for very large banks to extract rents both from informational advantages and from size-related safety-net subsidies. Our findings strongly reject the hypothesis that abnormal returns generated by FSMA events were entirely or even mainly due to gains in efficiency. Our data show that favored sectors' gains from FSMA not only came from decreases in the aggregate value of the stock of vulnerable customers, but also that losses at nonfinancial firms far outstripped financial firms’ gains.

That small, credit-constrained firms suffer negative event returns reinforces popular fears that the worldwide consolidation of the financial industry adversely affects capital-constrained firms. Happily, a notable surge in the flow of banking charters awarded in the U.S. supports the hypothesis that, over time, new entrants are seizing the opportunity to service such firms. Many of these new banking enterprises reclaim intangible relationship capital by employing bank executives whose jobs had evaporated in a prior consolidation. 


\section{REFERENCES}

Akhigbe, Aigbe and Ann Marie Whyte, 2001, The market's assessment of the Financial Services Modernization Act of 1999, Financial Review 36, 119 -138.

Akhigbe, Aigbe and Ann Marie Whyte, 2004, The Gramm-Leach-Bliley Act of 1999: Risk implications for the financial services industry, The Journal of Financial Research 27, 435-446.

Angzabo, Lazarus A., Jianping Mei and Anthony Saunders, 1998, Credit spreads in the market for highly leveraged transaction loans, Journal of Banking and Finance 22, 1249-1282.

Bae, Kee-Hong, Jun-Koo Kang and Chan-Woo Lim, 2002, The value of durable bank relationships: evidence from Korean banking shocks, Journal of Financial Economics 64, 181-214.

Berger, Allen N., Rebecca Demsetz and Philip Strahan, 1999, The consolidation of the financial services industry: causes, consequences, and implications for the future, Journal of Banking and Finance 23, 135-194.

Berger, Allen N., Anthony Saunders, Joseph M. Scalise, and Gregory F. Udell, 1998, The effects of bank mergers and acquisitions on small business lending, Journal of Financial Economics 50, 187-229.

Berger, Allen N., and Gregory F. Udell, 1995, Relationship lending and lines of credit in small firm finance, Journal of Business 68, 351-81.

Berger, Allen N., and Gregory F. Udel, 2002, Small business credit availability and relationship lending: The importance of bank organizational structure, Economic Journal 112, 32-53.

Berger, Allen N., Raghuram G. Rajan, Nathan H. Miller, Mitchell A. Petersen, and Jeremy C. Stein, 2004, Does function follow organizational form? Evidence from the lending practices of large and small banks, Journal of Financial Economics 76, 237-69.

Binder, J. J., 1997. The event study methodology since 1969, University of IllinoisChicago, working paper.

Binder, J. J., 1985a. On the use of the multivariate regression model in events studies, Journal of Accounting Research 23, 370-383.

Binder, J. J., 1985b. Measuring the effects of regulation with stock price data, Rand Journal of Economics 16, 167-183. 
Carow, Kenneth A., and Randall Heron, 2002, Capital market reactions to the passage of the Financial Services Modernization Act of 1999, Quarterly Review of Economics and Finance 42, 465-485.

Carow, Kenneth A., Edward J. Kane, and Rajesh P. Narayanan, 2004, How have borrowers fared in banking mega-mergers?, Journal of Money, Credit, and Banking (forthcoming).

Cetorelli, Nicola, and Michele Gambera, 2001, Banking market structure, financial dependence and growth: International evidence from industry data, Journal of Finance 56, 617-648.

Czyrnik, Kathy, and Linda Schmid Klein, 2004, Who benefits from deregulating the separation of banking activities? Differential effects on commercial bank, investment bank, and thrift stock returns, The Financial Review 39, 317-341.

Detragiache, Enrica., Paolo Garella, and Luigi Guiso, 2000, Multiple versus single banking relationships: Theory and evidence, Journal of Finance 55, 1133-1161.

Degryse, Hans, and Steven Ongena, 2005, Distance, lending relationships and competition, Journal of Finance 60, 231-266.

Diamond, Douglas W., 1984, Financial intermediation and delegated monitoring, Review of Economic Studies 51, 393-414.

Diamond, Douglas W., 1993, Seniority and maturity of debt contracts, Journal of Financial Economics 33, 341-368.

Drucker, Steven and Manju Puri, 2005, On the benefits of concurrent lending and underwriting, Journal of Finance, 60 (December), forthcoming.

Ely, David P. and Kenneth J. Robinson, 2004, The impact of banks' expanded securities powers on small business lending, Review of Financial Economics 13, 79-102.

Fazzari, S.M., R. Glenn Hubbard and B. C. Petersen, 1988, Financial constraints and corporate investment, Brookings Papers on Economic Activity 2, 141-195.

Frieswick, Kris, 2004, The two faces of bank mergers, CFO Magazine, March 1.

Gande, Amar, Manju Puri, and Anthony Saunders, 1999, Bank entry, competition, and the market for corporate securities underwriting, Journal of Financial Economics 54, 165-185.

Gertler, Mark and Simon Gilchrist, 1993, The role of credit market imperfections in the monetary transmission mechanism: arguments and evidence, Scandinavian Journal of Economics 95, 43-63. 
Hendershott, Robert J., Darrell E. Lee and James G. Tompkins, 2002, Winners and losers as financial service providers converge: Evidence from the Financial Modernization Act of 1999, Financial Review 37, 53-72.

Houston, Joel and Christopher James, 1996, Bank information monopolies and the mix of private and public debt claims, Journal of Finance 51, 1863-1889.

James, Chris, and David Smith, 2000, Are banks still special? New evidence on their role in the capital-raising process, Journal of Applied Corporate Finance 13(1), 52-63.

Jayaratne, Jith, and Philip E. Strahan, 1998, Entry restrictions, industry evolution, and dynamic efficiency, Journal of Law and Economics, 41(1), 239-74.

Kanatas, George and Jianping Qi, 2003, Integration of lending and underwriting: Implications of scope economies, The Journal of Finance 58, 1167-1191.

Kane, Edward J., 2000, Incentives for banking megamergers: What motives might regulators infer from event-study evidence? Journal of Money credit and Banking 32, 671-701

Kane, Edward J. and Burton G. Malkiel, 1965, Bank portfolio allocation, deposit variability, and the availability doctrine, Quarterly Journal of Economics 79, 113134.

Kang, Jun-Koo, and Rene M. Stulz, 2000, Do banking shocks affect borrowing firm performance? An analysis of the Japanese experience, Journal of Business 73, 123.

Kaplan, Steve N. and Luigi Zingales, 1997, Do investment-cash flow sensitivities provide useful measures of financing constraints? Quarterly Journal of Economics 112, 169-216.

Karceski, Jason, Steven Ongena, and David C. Smith, 2005, The impact of bank consolidation on commercial borrower welfare, Journal of Finance, 60, 20432082.

Kashyap, Anil K., Owen A. Lamont, and Jeremy Stein, 1994, Credit conditions and the cyclical behavior of inventories, Quarterly Journal of Economics 109, 565-592.

Korajczyk, Robert and Amnon Levy, 2003, Capital structure choice: macroeconomic conditions and financial constraints, Journal of Financial Economics 68, 75-109.

Ljungqvist, Alexander, Felicia Marston and William J. Wilhelm, 2005, Competing for securities underwriting mandates: Banking relationships and analyst recommendations, Journal of Finance, forthcoming. 
Ongena, Steven, David C. Smith, and Dag Michalsen, 2003, Firms and their distressed banks: Lessons from the Norwegian banking crisis, Journal of Financial Economics 67, 81-112.

Penas Maria F., and Haluk Unal, 2004, Gains in bank mergers: Evidence from the bond markets, Journal of Financial Economics, 74, 149-179.

Petersen, Mitchell, and Raghuram G. Rajan, 1994, The benefits of lending relationships: evidence from small business data, Journal of Finance 49, 3-37.

Rajan, Raghuram G., and Luigi Zingales, 1998, Financial dependence and growth, American Economic Review 88, 559-586.

Sapienza, Paola, 2002,The effects of banking mergers on loan contracts, Journal of Finance 57, 329-67.

Schwert, G. W., 1981, Using financial data to measure effects of regulation, Journal of Law and Economics 25, 121-158.

Slovin, Myron B., Marie E. Sushka, and John A. Polonchek, 1993, The value of bank durability: Borrowers as bank stakeholders, Journal of Finance 48, 247-266.

Stein, Jeremy. C., 2002, Information production and capital allocation: Decentralized versus hierarchical firms, Journal of Finance 57, 1891-1921.

Strahan, Philip E., and James P. Weston, 1998, Small business lending and the changing structure of the banking industry, Journal of Banking and Finance 22, 821-845.

Whited, Toni M. and Guojun Wu, 2005, Financial constraints risk, Review of Financial Studies, forthcoming.

Yasuda, Ayako, 2005, Do bank relationships affect the firm's underwriter choice in the corporate bond underwriting market? Journal of Finance, 60, 1259-1292.

$\mathrm{Yu}$, Lei, 2002, On the wealth and risk effects of the Glass-Steagall overhaul: evidence from the stock Market, New York University, Working paper.

Zellner, A., 1962, An efficient method of estimating seemingly unrelated regressions and test for aggregation bias, Journal of the American Statistical Association, 348368. 
Draft of October 5, 2005

Table 1: Legislative Progress Events

Event Date

Event

May 6, 1999

July 1, 1999

October 13, 1999

October 15, 1999

October 22, 1999

November 2, 1999

November 4, 1999

November 12, 1999
Senate approves Financial Services Modernization Act of 1999 (S.900) 55-44. President Clinton threatens a veto over provisions concerning the Community Reinvestment Act.

House of Representatives approves H.R.10 by margin of 343-86.

Significant progress in reconciling the House and Senate bills is announced.

Federal Reserve and Treasury Department announce agreement on responsibility for regulating Financial Holding Companies and bank subsidiaries.

Early-morning negotiations eliminate the threat of a presidential veto. White House and Conference Committee agree on compromise provisions.

Conference report is signed by majority of conferees, clearing the way for floor votes in the House and Senate.

Financial Services Modernization Act passes the Senate 90-8 and the House 362-57.

President Clinton signs the Financial Services Modernization Act. 


\section{Table 2: Intersectoral tests}

Abnormal returns and changes in beta are computed using a multivariate regression model. To compute abnormal returns, a benchmark model is estimated using returns from January 1, 1999 to November 15, 1999. A benchmark for Beta changes is estimated by adding an additional 6 months of returns on either side of the abnormal return estimation period, i.e. from July 1, 1998 to May 15, 2000.

\begin{tabular}{|c|c|c|}
\hline & Financial & Customers \\
\hline Number of Companies & 682 & 3008 \\
\hline \multicolumn{3}{|l|}{ Panel A: Abnormal Returns } \\
\hline Cumulative abnormal return (CAR) & $1.20 \%$ & $-2.53 \%$ \\
\hline t-statistic for $\mathrm{H}_{0}: \mathrm{CAR}=0$ & 0.66 & $-3.30 * * *$ \\
\hline Percent positive CARs & 57.48 & 43.35 \\
\hline z-statistic for $\mathrm{H}_{0}: \%$ positive CAR $=50 \%$ & $3.91 * * *$ & $-7.29 * * *$ \\
\hline \multicolumn{3}{|l|}{ Panel B: Systematic Risk (beta) } \\
\hline Pre-beta (7/1/98 - 12/31/98) & 0.90 & 1.10 \\
\hline Post-beta $(11 / 16 / 99-5 / 15 / 00)$ & 0.37 & 0.92 \\
\hline t-statistic for $\mathrm{H}_{0}$ : beta change (pre to post) $=0$ & $-12.09 * * *$ & $-9.63 * * *$ \\
\hline Percent positive beta changes & $11.29 \%$ & $30.49 \%$ \\
\hline z-statistic for $\mathrm{H}_{0}: \%$ positive beta changes $=50 \%$ & $-20.22 * * *$ & $-21.41 * * *$ \\
\hline \multicolumn{3}{|l|}{ Panel C: Cross-sectoral hypotheses tests } \\
\hline $\begin{array}{l}\text { p-value of F-test for } \mathrm{H}_{0} \text { : CAR for financial portfolio } \\
=\text { CAR for customer portfolio }\end{array}$ & \multicolumn{2}{|c|}{0.0248} \\
\hline $\begin{array}{l}\text { p-value of Wilcoxon rank sum test for } \mathrm{H}_{0}: \text { CAR for } \\
\text { financial portfolio = CAR for customer portfolio }\end{array}$ & \multicolumn{2}{|c|}{$<0.0001$} \\
\hline $\begin{array}{l}\text { p-value of F-test for } \mathrm{H}_{0}: \text { CAR for financial portfolio } \\
+ \text { CAR for customer portfolio }=0\end{array}$ & \multicolumn{2}{|c|}{0.5550} \\
\hline
\end{tabular}

\footnotetext{
*** Significant at the $1 \%$ level
} 
Draft of October 5, 2005

Table 3: Intrasectoral Differences within the Financial Sector

Abnormal returns are computed using a multivariate regression model and data from January 1, 1999 to November 15, 1999.

\begin{tabular}{|c|c|c|c|c|c|c|c|}
\hline & \multicolumn{7}{|c|}{ Financial Sector } \\
\hline & $\begin{array}{c}\text { Finance } \\
\text { Companies }\end{array}$ & $\begin{array}{r}\text { Insurance } \\
\text { Agencies }\end{array}$ & $\begin{array}{l}\text { Insurance } \\
\text { Companies }\end{array}$ & $\begin{array}{c}\text { Investment } \\
\text { Banks }\end{array}$ & $\begin{array}{c}\text { Commercial } \\
\text { Banks }\end{array}$ & $\begin{array}{c}\text { Section20 } \\
\text { banks }\end{array}$ & Thrifts \\
\hline Number of firms & 33 & 22 & 95 & 45 & 268 & 25 & 194 \\
\hline Cumulative Abnormal Return (CAR) & $-5.15 \%$ & $-0.80 \%$ & $5.33 \%$ & $3.40 \%$ & $1.22 \%$ & $2.23 \%$ & $-0.18 \%$ \\
\hline t-statistic for $\mathrm{H}_{0}: \mathrm{CAR}=0$ & -1.22 & -0.22 & $1.99 *$ & 0.80 & 0.63 & 0.33 & -0.11 \\
\hline Percent positive CARs & 33.33 & 31.82 & $76.8 \%$ & 62.22 & 60.08 & 68.00 & 48.97 \\
\hline z-statistic for $\mathrm{H}_{0}: \%$ positive $\mathrm{CAR}=50 \%$ & $-1.91 *$ & $-1.71^{*}$ & $5.23^{* * *}$ & 1.64 & $3.30^{* * *}$ & $1.80^{*}$ & -0.29 \\
\hline
\end{tabular}

*** Significant at the $1 \%$ level

* Significant at the $10 \%$ level 


\section{Table 4: Differences within the Customer Sector}

Abnormal returns and changes in beta are computed using a multivariate regression model. To compute abnormal returns, the model is estimated using returns from January 1, 1999 to November 15, 1999. Beta changes are benchmarked by adding an additional 6 months of returns on either side of the abnormal-return estimation period, i.e. from July 1, 1998 to May 15, 2000.

\begin{tabular}{|c|c|c|}
\hline & \multicolumn{2}{|c|}{ Customer Sector } \\
\hline & $\begin{array}{c}\text { Credit } \\
\text { constrained }\end{array}$ & $\begin{array}{c}\text { Credit- } \\
\text { unconstrained }\end{array}$ \\
\hline Number of firms & 722 & 2286 \\
\hline \multicolumn{3}{|l|}{ Panel A : Abnormal Returns } \\
\hline Cumulative Abnormal Return (CAR) & $-5.22 \%$ & $-1.68 \%$ \\
\hline t-statistic for $\mathrm{H}_{0}: \mathrm{CAR}=0$ & $-3.55 * * *$ & -1.49 \\
\hline Percent positive CARs & 38.92 & 44.75 \\
\hline $\begin{array}{l}\text { z-statistic for } \mathrm{H}_{0}: \% \text { positive } \mathrm{CAR}= \\
\quad 50 \%\end{array}$ & $-5.95 * * *$ & $-5.02 * * *$ \\
\hline \multicolumn{3}{|l|}{ Panel B: Systematic Risk } \\
\hline Pre-beta (7/1/98 - 12/31/98) & 1.32 & 1.03 \\
\hline Post-beta $(11 / 16 / 99-5 / 15 / 00)$ & 1.52 & 0.73 \\
\hline $\begin{array}{l}\text { t-statistic for beta change from pre to } \\
\text { post }\end{array}$ & $5.59 * * *$ & $-10.86 * * *$ \\
\hline Percent positive beta changes & 49.17 & 24.58 \\
\hline $\begin{array}{l}\text { z-statistic for } \mathrm{H}_{0}: \% \text { positive beta } \\
\text { changes }=50 \%\end{array}$ & -0.45 & $-24.30 * * *$ \\
\hline \multicolumn{3}{|l|}{$\begin{array}{l}\text { Panel C: Cross -sectoral hypotheses } \\
\text { tests }\end{array}$} \\
\hline $\begin{array}{l}\mathrm{p} \text {-value for } \mathrm{F} \text { test and Wilcoxon rank } \\
\text { sum test for } \mathrm{H}_{0} \text { : CAR for constrained } \\
\text { customers }=\mathrm{CAR} \text { for unconstrained } \\
\text { customers }\end{array}$ & 0.1111 & $<0.0001$ \\
\hline $\begin{array}{l}\text { p-value for F-test and Wilcoxon rank } \\
\text { sum test for } \mathrm{H}_{0} \text { : beta changes for } \\
\text { constrained customers = beta changes } \\
\text { for unconstrained customers }\end{array}$ & $<0.0001$ & $<0.0001$ \\
\hline
\end{tabular}

\footnotetext{
*** Significant at the $1 \%$ level
} 
Table 5: Cross-sectional analysis of customers

Abnormal returns and changes in beta are estimated using a multivariate regression model. To compute abnormal returns, the model is estimated using returns from January 1, 1999 to November 15, 1999. Beta changes are benchmarked by adding an additional 6 months of returns on either side of the abnormal return estimation period, i.e. from July 1, 1998 to May 15, 2000. Variable definitions are provided in the Appendix. t-values corrected using White's procedure appear in parentheses below coefficient estimates.

\begin{tabular}{|c|c|c|}
\hline & $\begin{array}{r}C A R \\
\mathbf{I} \\
\end{array}$ & $\begin{array}{c}\text { BETACHANGE } \\
\text { II } \\
\end{array}$ \\
\hline Intercept & $\begin{array}{l}-0.0521 \\
(-5.26)^{* * *}\end{array}$ & $\begin{array}{l}0.3006 \\
(4.81)^{* * *}\end{array}$ \\
\hline SECTION20 & $\begin{array}{l}-0.0011 \\
(-0.20)\end{array}$ & $\begin{array}{l}-0.1729 \\
(-5.33)^{* * *}\end{array}$ \\
\hline EFN & $\begin{array}{l}-0.0003 \\
(-0.51)\end{array}$ & $\begin{array}{l}0.0164 \\
(3.94)^{* * *}\end{array}$ \\
\hline SIZE & $\begin{array}{l}0.0062 \\
(3.65)^{* * *}\end{array}$ & $\begin{array}{c}-0.1066 \\
(-10.16)^{* * *}\end{array}$ \\
\hline PUB_DEBT & $\begin{array}{l}-0.0113 \\
(-1.97)^{* *}\end{array}$ & $\begin{array}{l}0.0693 \\
(2.14)^{* *}\end{array}$ \\
\hline MUL_REL & $\begin{array}{l}-0.0034 \\
(-0.54)\end{array}$ & $\begin{array}{l}0.0393 \\
(1.10)\end{array}$ \\
\hline AGE & $\begin{array}{l}0.0012 \\
(0.56)\end{array}$ & $\begin{array}{c}0.0355 \\
(2.89)^{* * *}\end{array}$ \\
\hline CREDIT_CONSTRAINED & $\begin{array}{l}-0.0216 \\
(-4.02)^{* * *}\end{array}$ & $\begin{array}{l}0.1407 \\
(3.13)^{* * *}\end{array}$ \\
\hline $\begin{array}{l}\text { Number of Observations } \\
\text { R-squared } \\
\text { Adjusted R-squared } \\
\text { P-value on F-stat }\end{array}$ & $\begin{array}{l}3008 \\
0.0197 \\
0.0174 \\
<.0001\end{array}$ & $\begin{array}{c}3008 \\
0.1313 \\
0.1292 \\
<.0001\end{array}$ \\
\hline
\end{tabular}

*** Significant at the $1 \%$ level

** Significant at the $5 \%$ level

* Significant at the $10 \%$ level 


\section{Table 6}

\section{Robustness tests of the cross-sectional model of cumulative abnormal returns}

This table summarizes robustness tests of the model of cumulative abnormal returns. The endogenous variable is the cumulative abnormal return over the eight events listed in Table 1. Each column provides incremental evidence about robustness. Model 1 restricts the sample to firms where LPC data are available. We interpret this as "sampling current customers only." Model 2 respecifies the CAR model to include a series of indicator variables identifying the one-digit SIC code of the company. Industry effects as well as intercepts are not shown in the table. Model 3 respecifies the indicator variables to identify the two-digit SIC code of the company. Again, industry effects and intercepts are not shown in the table. Model 4 includes additional Compustat variables as control variables. TOBINQ equals the market value of assets divided by book value of assets (data6-data60+data24*data25)/data6. DEBT_ASSET equals the total debt divided by assets (data9 / data6). $\mathrm{R} \& \mathrm{D}$ is an indicator variable equal to 1 if the firm has research and development expenditures (data46 $>0$; 0 otherwise). DIVIDEND is an indicator variable equal to 1 if the firm paid dividends on their common stock (data26 $>0$; 0 otherwise). TOBINQ and DEBT_ASSET are winsorized at the $5^{\text {th }}$ and $95^{\text {th }}$ percentiles.

\begin{tabular}{|c|c|c|c|c|}
\hline & LPC Sample & $\begin{array}{c}\text { Model } 2 \\
\text { Full-Sample } \\
\text { 1-digit SIC }\end{array}$ & $\begin{array}{c}\text { Model } 3 \\
\text { Full-Sample } \\
\text { 2-digit SIC }\end{array}$ & $\begin{array}{c}\text { Model } 4 \\
\text { Additional } \\
\text { Control } \\
\text { Variables }\end{array}$ \\
\hline Intercept & $\begin{array}{c}-0.0633 \\
(-3.66) * * *\end{array}$ & & & $\begin{array}{c}-0.0411 \\
(-3.75) * * *\end{array}$ \\
\hline SI ZE & $\begin{array}{l}0.0068 \\
(2.40) * *\end{array}$ & $\begin{array}{c}0.0056 \\
(3.22) * * *\end{array}$ & $\begin{array}{c}0.0052 \\
(3.00) * * *\end{array}$ & $\begin{array}{l}0.0049 \\
(2.71) * * *\end{array}$ \\
\hline SECTI ON20 & $\begin{array}{l}0.0129 \\
(1.29)\end{array}$ & $\begin{array}{l}0.0005 \\
(0.10)\end{array}$ & $\begin{array}{l}-0.0002 \\
(-0.03)\end{array}$ & $\begin{array}{l}-0.0016 \\
(-0.28)\end{array}$ \\
\hline PUB_DEBT & $\begin{array}{l}-0.0209 \\
(-2.46) * *\end{array}$ & $\begin{array}{l}-0.0096 \\
(-1.53)\end{array}$ & -0.0070 & $\begin{array}{l}-0.0094 \\
(-1.45)\end{array}$ \\
\hline ML_REL & $\begin{array}{l}-0.0005 \\
(-0.07)\end{array}$ & $\begin{array}{l}-0.0033 \\
(-0.49)\end{array}$ & $\begin{array}{l}-0.0034 \\
(-0.50)\end{array}$ & $\begin{array}{l}-0.0014 \\
(-0.21)\end{array}$ \\
\hline EFN & 0.0002 & $\begin{array}{l}-0.0003 \\
(-0.63)\end{array}$ & $\begin{array}{l}-0.0004 \\
(-0.73)\end{array}$ & $\begin{array}{l}-0.0001 \\
(-0.11)\end{array}$ \\
\hline AGE & $\begin{array}{l}-0.0005 \\
(-0.15)\end{array}$ & $\begin{array}{l}0.0015 \\
(0.70)\end{array}$ & $\begin{array}{l}0.0007 \\
(0.31)\end{array}$ & $\begin{array}{l}-0.0014 \\
(-0.60)\end{array}$ \\
\hline CREDI T_CONSTRAI NED & $\begin{array}{c}-0.0258 \\
(-2.40) * *\end{array}$ & $\begin{array}{c}-0.0211 \\
(-3.31) * * *\end{array}$ & $\begin{array}{c}-0.0223 \\
(-3.49) * * *\end{array}$ & $\begin{array}{c}-0.0204 \\
(-3.15) * * *\end{array}$ \\
\hline TOBI NSQ & & & & $\begin{array}{l}-0.0027 \\
(-2.00) * *\end{array}$ \\
\hline DEBT_ASSET & & & & $\begin{array}{l}-0.0119 \\
(-0.91)\end{array}$ \\
\hline $\mathrm{R} \& D$ & & & & $\begin{array}{l}0.0070 \\
(1.60)\end{array}$ \\
\hline DI VI DEND & & & & $\begin{array}{c}0.0155 \\
(2.86) * * *\end{array}$ \\
\hline Number of Observations & 1218 & 3008 & 3008 & 2920 \\
\hline R-squared & 0.0179 & 0.0297 & 0.0526 & 0.0239 \\
\hline Adjusted R-squared & 0.0122 & 0.0248 & 0.0376 & 0.0202 \\
\hline P-value on F-stat & $<0026$ & $<0001$ & $<0001$ & $<0001$ \\
\hline
\end{tabular}

$* * *$ Significant at the $1 \%$ level $* *$ Significant at the $5 \%$ level 


\section{Table 7}

\section{Robustness tests of the cross-sectional model of changes in beta}

This table summarizes robustness tests related to the model explaining changes in beta. Beta changes are benchmarked by comparing the beta estimated for 6 months of returns prior to the legislative period to the beta estimated for the 6 months following the legislative period. Each column provides evidence about robustness. Model 1 restricts the sample to firms for which LPC data are available. We interpret this as "sampling current customers only." Model 2 respecifies the CAR model to include a series of indicator variables identifying the one-digit SIC code of the company. Model 3 respecifies the indicator variables to identify the two-digit SIC code of the company. Industry effects and intercepts are not shown in the table for models 2 and 3 . Model 4 includes additional Compustat variables as control variables. TOBINQ equals the market value of assets divided by book value of assets (data6-data60+data24*data25)/data6. DEBT_ASSET equals the total debt divided by assets (data9 / data6). R\&D is an indicator variable equal to 1 if the firm has research and development expenditures (data46 $>0$; 0 otherwise). DIVIDEND is an indicator variable equal to 1 if the firm paid dividends on their common stock (data26 > 0; 0 otherwise). TOBINQ and DEBT_ASSET are winsorized at the $5^{\text {th }}$ and $95^{\text {th }}$ percentiles.

\begin{tabular}{|c|c|c|c|c|}
\hline & Model 1 & $\begin{array}{c}\text { Model } 2 \\
\text { Full-Sample } \\
\text { 1-digit SIC }\end{array}$ & $\begin{array}{c}\text { Model } 3 \\
\\
\text { Full-Sample } \\
\text { 2-digit SIC }\end{array}$ & $\begin{array}{c}\text { Model } 4 \\
\text { Additional } \\
\text { Control } \\
\text { Variables }\end{array}$ \\
\hline Intercept & $\begin{array}{l}0.0764 \\
(0.79)\end{array}$ & & & $\begin{array}{c}0.1169 \\
(1.77) *\end{array}$ \\
\hline SI ZE & $\begin{array}{c}-0.0702 \\
(-4.43) * * *\end{array}$ & $\begin{array}{c}-0.1012 \\
(-9.55) * * *\end{array}$ & $\begin{array}{c}-0.0953 \\
(-9.08) * * *\end{array}$ & $\begin{array}{c}-0.0907 \\
(-8.30) * * *\end{array}$ \\
\hline SECTI ON20 & $\begin{array}{l}-0.1078 \\
(-1.94) *\end{array}$ & $\begin{array}{c}-0.1648 \\
(-4.82) * * *\end{array}$ & $\begin{array}{c}-0.1514 \\
(-4.50) * * *\end{array}$ & $\begin{array}{c}-0.1081 \\
(-3.14)^{* * *}\end{array}$ \\
\hline PUB_DEBT & $\begin{array}{l}0.0173 \\
(0.37)\end{array}$ & 0.0508 & 0.0688 & 0.0665 \\
\hline MU__REL & $\begin{array}{l}-0.0160 \\
(-0.40)\end{array}$ & $\begin{array}{l}0.0367 \\
(0.89)\end{array}$ & $\begin{array}{l}1.0197 \\
(0.019)\end{array}$ & $\begin{array}{l}0.0303 \\
(0.73)\end{array}$ \\
\hline EFN & $\begin{array}{l}-0.0049 \\
(-0.82)\end{array}$ & $\begin{array}{c}0.0183 \\
(5.46) * * *\end{array}$ & $\begin{array}{c}0.0143 \\
(4.32) * * *\end{array}$ & $\begin{array}{c}0.0161 \\
(4.67)^{* * *}\end{array}$ \\
\hline AGE & $\begin{array}{c}0.0316 \\
(1.83) *\end{array}$ & $\begin{array}{c}0.0340 \\
(2.61) * * *\end{array}$ & $\begin{array}{l}0.0313 \\
(2.40) * *\end{array}$ & $\begin{array}{l}0.0328 \\
(2.37)^{* *}\end{array}$ \\
\hline CREDI T_CONSTRAI NED & $\begin{array}{l}0.0569 \\
(0.95)\end{array}$ & $\begin{array}{l}0.1239 \\
(3.17) * * *\end{array}$ & $\begin{array}{l}0.1280 \\
(3.33) * * *\end{array}$ & $\begin{array}{l}0.1307 \\
(3.37) * * *\end{array}$ \\
\hline TOBI NSQ & & & & $\begin{array}{l}0.0072 \\
(0.90)\end{array}$ \\
\hline DEBT_ASSET & & & & $\begin{array}{l}-0.1771 \\
(-2.25) * *\end{array}$ \\
\hline$R \& D$ & & & & $\begin{array}{c}0.2868 \\
(10.87)^{* * *}\end{array}$ \\
\hline DI VI DEND & & & & $\begin{array}{l}-0.0530 \\
(-1.63)\end{array}$ \\
\hline Number of Observations & 1218 & 3008 & 3008 & 2920 \\
\hline R-squared & 0.0458 & 0.1578 & 0.2082 & 0.1781 \\
\hline Adjusted R-squared & 0.0403 & 0.1536 & 0.1956 & 0.1750 \\
\hline P-value on F-stat & $<0001$ & $<0001$ & $<0001$ & $<0001$ \\
\hline
\end{tabular}

*** Significant at the $1 \%$ level ** Significant at the $5 \%$ level ** Significant at the $10 \%$ level 


\section{Table 8}

\section{Correlations Between Alternative Measures of Financial Constraint}

Given that all three alternative measures of financial constraint are composites of the control variables used in our cross-sectional regression models, the original control variables are collinear with each of the alternative measures. For this reason, we do not report cross-sectional regressions using the alternative measures. The upper portion of the correlation table describes the bivariate correlation that exists between the four measures of financial constraints. The lower portion of the table reports the correlations that the different measures have with abnormal returns and changes in beta. We note that, unlike the other indices, Whited and Wu's (2005) index of financial constraint is an inverse measure. Hence, all indices show that financially constrained firms have lower abnormal returns and larger increases in systematic risk. Whited and Wu's (2005) measure represents financial constraint as [-.062*(debt to assets) $+.010 *$ (indicator for positive dividends $)+.067 *(1$ plus the growth in the firm's sales $)+.060 *(\log$ of assets $)-.043 *(1$ plus the growth in industry sales) $+.053^{*}$ (cash flow to assets)]. Kaplan and Zingales (1997) measure financial constraint as [-1.001909*(cash flow to assets) $+3.139193 *$ (debt to assets) $-39.36780 *$ (dividends to assets) - 1.314759*(liquid cash to assets) + .2826389*(Tobin’s Q)]. Korajczyk and Levy (KL) (2003, p.82) define a firm as financially constrained if: "(1)the firm does not have a net repurchase of debt or equity and does not pay dividends within the event window, and (2) its Tobin's Q, (defined as the sum of the market value of equity and the book value of debt, divided by the book value of assets), at the end of the event quarter...[is] greater than one.” As an indicator variable, the KL index correlates more closely with our indicator that the other indices.

\section{Correlation Matrix (p-values are reported below coefficient estimates)}

\begin{tabular}{lrrrr} 
Sample & Credit & Whited & Kaplan \& & Korajczyk \\
Size & Constrained & \& Wu & Zingales & \& Levy \\
\hline
\end{tabular}

\begin{tabular}{|c|c|c|c|c|c|}
\hline \multicolumn{6}{|c|}{ Alternative measures of financial constraint } \\
\hline $\begin{array}{l}\text { Credit } \\
\text { Constrained }\end{array}$ & 3008 & 1.0000 & $\begin{array}{r}-0.2338 \\
<.0001\end{array}$ & $\begin{array}{l}0.1025 \\
<.0001\end{array}$ & $\begin{array}{l}0.2723 \\
<.0001\end{array}$ \\
\hline $\begin{array}{l}\text { Whited \& } \\
\text { Wu }\end{array}$ & 2210 & $\begin{array}{r}-0.2338 \\
<.0001\end{array}$ & 1.0000 & $\begin{array}{l}0.0778 \\
<.0003\end{array}$ & $\begin{array}{r}-0.3188 \\
<.0001\end{array}$ \\
\hline $\begin{array}{l}\text { Kaplan \& } \\
\text { Zingales }\end{array}$ & 2199 & $\begin{array}{l}0.1025 \\
<.0001\end{array}$ & $\begin{array}{l}0.0778 \\
<.0003\end{array}$ & 1.0000 & $\begin{array}{l}0.3626 \\
<.0001\end{array}$ \\
\hline $\begin{array}{l}\text { Korajczyk \& } \\
\text { Levy }\end{array}$ & 2236 & $\begin{array}{l}0.4774 \\
<.0001\end{array}$ & $\begin{array}{r}-0.1916 \\
<.0001\end{array}$ & $\begin{array}{l}0.2685 \\
<.0001\end{array}$ & 1.0000 \\
\hline
\end{tabular}

Correlations with abnormal returns and changes in beta

\begin{tabular}{|c|c|c|c|c|c|}
\hline \multirow[t]{2}{*}{ CAR } & \multirow[t]{2}{*}{3008} & -0.1197 & 0.0578 & -0.0462 & -0.1029 \\
\hline & & $<.0001$ & 0.0065 & 0.0302 & 0.0001 \\
\hline \multirow[t]{2}{*}{ BETA_CHANGE } & \multirow[t]{2}{*}{3008} & 0.2305 & -0.1898 & -0.0876 & 0.1249 \\
\hline & & $<.0001$ & $<.0001$ & 0.0001 & 0.0001 \\
\hline
\end{tabular}


Draft of October 5, 2005

\section{Appendix: Variable Definitions}

\begin{tabular}{|c|c|}
\hline Variable Name & Description \\
\hline CAR & $\begin{array}{l}\text { The Cumulative Abnormal return over each of the eight events listed in Table } 1 . \\
\text { Each event window combines the day of the event with the day following the } \\
\text { announcement. Values winsorized at the } 5^{\text {th }} \text { and } 95^{\text {th }} \text { percentiles are used in cross- } \\
\text { sectional tests. }\end{array}$ \\
\hline BETACHANGE & $\begin{array}{l}\text { Calculated change in beta between the six-month period preceding the January } 1 \text {, } \\
1999(7 / 1 / 98 \text { to } 12 / 31 / 98) \text { and the six-month period following the passage of } \\
\text { FSMA (11/15/99 to } 5 / 15 / 00) \text {. Values winsorized at the } 5^{\text {th }} \text { and } 95^{\text {th }} \text { percentiles are } \\
\text { used in cross-sectional tests. }\end{array}$ \\
\hline EFN & $\begin{array}{l}\text { The average value found for external financing needs during the last } 3 \text { years. } \\
\text { External financing needs are defined as planned investments - internally available } \\
\text { funds (From COMPUSTAT (data128 - (data18 + data14) }+(\text { data } 3-\text { data3a) }+ \\
\text { (data2 - data2a) - (data70 - data70a) - (data71 - data71a))/data128. If less than } 3 \\
\text { years of data are available, we use the available data. Averages are winsorized at } \\
\text { the } 5^{\text {th }} \text { and } 95^{\text {th }} \text { percentiles. }\end{array}$ \\
\hline SECTION20 & $\begin{array}{l}\text { An indicator variable that equals } 1 \text { if the firm is a customer of a section } 20 \text { bank } \\
\text { and is } 0 \text { otherwise. Section } 20 \text { banks are identified from the Federal Reserve web- } \\
\text { site. }\end{array}$ \\
\hline PUB_DEBT & $\begin{array}{l}\text { An indicator variable that equals } 1 \text { if the firm has public debt outstanding and is } 0 \\
\text { otherwise. The presence of public debt is identified from COMPUSTAT. }\end{array}$ \\
\hline SIZE & $\begin{array}{l}\text { The log value of the firm's assets in \$millions (COMPUSTAT data6), winsorized } \\
\text { at the } 5^{\text {th }} \text { and } 95^{\text {th }} \text { percentile. }\end{array}$ \\
\hline AGE & $\begin{array}{l}\text { The log of the number of years that the company has been listed on the NYSE, } \\
\text { AMEX, or NASDAQ as identified from CRSP. The maximum number of years } \\
\text { was set at } 25 \text {. }\end{array}$ \\
\hline MUL_REL & $\begin{array}{l}\text { An indicator variable that equals } 1 \text { if the firm has more than one banking } \\
\text { relationship during the period January } 1,1999 \text { to November 15, 1999, and is } 0 \\
\text { otherwise. Identified from LPC Dealscan database. }\end{array}$ \\
\hline CREDIT_CONSTAINED & $\begin{array}{l}\text { An indicator variable that takes on the value of } 1 \text { if the firm is credit-constrained } \\
\text { and } 0 \text { otherwise. Credit-constrained customers are firms that have EFN }>0 \text {, } \\
\text { PUB_DEBT }=0 \text {, AGE }<\text { Log of } 11 \text { years, SIZE }<\text { Log of } \$ 500 \text { million and } \\
\text { MUL_REL }=0 \text {. }\end{array}$ \\
\hline
\end{tabular}




\section{Appendix A}

\section{Aggregate Gains and Losses for Financial and Nonfinancial Firms}

In the table below, we show our estimates of the aggregate gains and losses for financial and nonfinancial firms. In the most recently available Census report prior to the passage of FSMA, Enterprise Statistics 1992, "Table 4, Company Statistics by Receipt Size: 1992"

[http://www.census.gov/prod/3/97pubs/es-9201.pdf], we obtain the number of public and private firms in the financial and nonfinancial industries. For each firm in our dataset, we define the dollar impact as the cumulative abnormal return of the individual firm multiplied by the firm's market capitalization on May 5, 1999. We separate our CRSP and Compustat data into receipt categories as defined in the Census report and for each category calculate the median dollar impact. To obtain the total industry impact, we multiply the number of firms reported in the census report by the median dollar impact from our sample and sum the values across the receipt categories. Due to the small number of observations in CRSP and Compustat for firms under \$2.5 million in receipts, we omit these firms from this analysis. Given that smaller, more credit constrained nonfinancial firms are expected to have the largest losses, we assume that this increases the conservative nature of our estimate.

\begin{tabular}{|c|c|c|c|c|c|c|c|c|c|}
\hline $\begin{array}{l}\text { Receipts per } \\
\text { firm (in } \\
\text { millions) } \\
\end{array}$ & $\begin{array}{l}\text { \# Public } \\
\text { and } \\
\text { Private } \\
\text { Firms } \\
\end{array}$ & $\begin{array}{c}\text { \# Public } \\
\text { and Private } \\
\text { Firms (ex. } \\
\text { Financial) } \\
\end{array}$ & $\begin{array}{c}\text { \# Non- } \\
\text { financial } \\
\text { Firms in } \\
\text { Our } \\
\text { Database } \\
\end{array}$ & $\begin{array}{c}\text { Median } \\
\text { Dollar Impact } \\
\text { of FSMA per } \\
\text { firm (in } \\
\text { thousands) } \\
\end{array}$ & $\begin{array}{l}\text { Dollar Impact } \\
\text { per receipt } \\
\text { sector (in } \\
\text { thousands) } \\
\end{array}$ & $\begin{array}{l}\text { \# Public } \\
\text { and } \\
\text { Private } \\
\text { Financial } \\
\text { Firms } \\
\end{array}$ & $\begin{array}{l}\text { \# Financial } \\
\text { Firms in } \\
\text { Our } \\
\text { Database } \\
\end{array}$ & $\begin{array}{c}\text { Median } \\
\text { Dollar Impact } \\
\text { of FSMA per } \\
\text { firm (in } \\
\text { thousands) } \\
\end{array}$ & $\begin{array}{l}\text { Dollar Impact } \\
\text { per receipt } \\
\text { sector (in } \\
\text { thousands) } \\
\end{array}$ \\
\hline $2.5-4.9$ & 170,104 & 158,994 & 31 & $(\$ 1,751)$ & $(\$ 278,462,092)$ & 11,110 & 4 & 1,119 & $12,431,090$ \\
\hline $5-9.9$ & 94,547 & 88,156 & 75 & $(1,233)$ & $(108,669,901)$ & 6,391 & 12 & (47) & $(302,186)$ \\
\hline $10-24.9$ & 60,999 & 56,652 & 187 & (679) & $(38,451,639)$ & 4,347 & 64 & (225) & $(979,205)$ \\
\hline $25-49.9$ & 19,982 & 18,522 & 233 & (881) & $(16,316,697)$ & 1,460 & 102 & (141) & $(206,205)$ \\
\hline $50-99.9$ & 9,220 & 8,381 & 305 & (599) & $(5,024,159)$ & 839 & 116 & 993 & 833,204 \\
\hline $100-249$ & 5,028 & 4,468 & 518 & $(2,167)$ & $(9,681,262)$ & 560 & 127 & 1,734 & 970,878 \\
\hline $250-499$ & 1,761 & 1,494 & 389 & $(2,615)$ & $(3,906,138)$ & 267 & 70 & 17,703 & $4,726,621$ \\
\hline $500-1000$ & 954 & 796 & 347 & $(2,888)$ & $(2,299,007)$ & 158 & 54 & 9,523 & $1,504,609$ \\
\hline $1000-2500$ & 645 & 522 & 363 & $(2,081)$ & $(1,086,292)$ & 123 & 40 & 62,800 & $7,724,345$ \\
\hline$>2500$ & 452 & 356 & 343 & $(9,747)$ & $(3,469,978)$ & 96 & 68 & 385,361 & $36,994,620$ \\
\hline Totals & 363,692 & 338,341 & 2,791 & & $(\$ 467,367,165)$ & 25,351 & 657 & & $\$ 63,697,770$ \\
\hline
\end{tabular}




\section{Appendix A [Table omits the first two categories for Financial Firms, due to small sample size] Estimates of FSMA-Induced Aggregate Gains and Losses Across the Populations of US Financial and Nonfinancial Firms}

This table shows our estimates of the aggregate gains and losses for financial and nonfinancial firms. From the most recently available Census report prior to the passage of FSMA, Enterprise Statistics 1992, "Table 4, Company Statistics by Receipt Size: 1992"

[http://www.census.gov/prod/3/97pubs/es-9201.pdf], we obtain the number of public and private firms in the financial and nonfinancial industries. For each firm in our dataset, we define the dollar impact as the cumulative abnormal return of the individual firm multiplied by the firm's market capitalization on May 5, 1999. We separate CRSP and Compustat data into ten receipt classes used in the Census report and for each category calculate the median dollar impact. To estimate the total industry impact, we multiply the number of firms reported in the census report by the median dollar impact shown in our sample and sum the values across the receipt categories. Due to the small number of observations in CRSP and Compustat for firms under $\$ 2.5$ million in receipts, we omit these firms from this analysis. Because smaller, more credit-constrained nonfinancial firms are expected to have large losses, this omission is apt to understate the effect on nonfinancial firms.

\begin{tabular}{|c|c|c|c|c|c|c|c|c|c|}
\hline $\begin{array}{l}\text { Receipts per } \\
\text { firm (in } \\
\text { millions) } \\
\end{array}$ & $\begin{array}{l}\text { \# Public } \\
\text { and } \\
\text { Private } \\
\text { Firms }\end{array}$ & $\begin{array}{c}\text { \# Public } \\
\text { and Private } \\
\text { Firms (ex. } \\
\text { Financial) }\end{array}$ & $\begin{array}{c}\text { \# Non- } \\
\text { financial } \\
\text { Firms in } \\
\text { Our } \\
\text { Database } \\
\end{array}$ & $\begin{array}{c}\text { Median } \\
\text { Dollar Impact } \\
\text { of FSMA per } \\
\text { firm (in } \\
\text { thousands) } \\
\end{array}$ & $\begin{array}{l}\text { Dollar Impact } \\
\text { per receipt } \\
\text { sector (in } \\
\text { thousands) } \\
\end{array}$ & $\begin{array}{l}\text { \# Public } \\
\text { and } \\
\text { Private } \\
\text { Financial } \\
\text { Firms } \\
\end{array}$ & $\begin{array}{c}\text { \# Financial } \\
\text { Firms in } \\
\text { Our } \\
\text { Database } \\
\end{array}$ & $\begin{array}{c}\text { Median } \\
\text { Dollar Impact } \\
\text { of FSMA per } \\
\text { firm (in } \\
\text { thousands) } \\
\end{array}$ & $\begin{array}{l}\text { Dollar Impact } \\
\text { per receipt } \\
\text { sector (in } \\
\text { thousands) } \\
\end{array}$ \\
\hline $2.5-4.9$ & 170,104 & 158,994 & 31 & $(\$ 1,751)$ & $(\$ 278,462,092)$ & 11,110 & 4 & Insufficient & \\
\hline $5-9.9$ & 94,547 & 88,156 & 75 & $(1,233)$ & $(108,669,901)$ & 6,391 & 12 & Data & \\
\hline $10-24.9$ & 60,999 & 56,652 & 187 & (679) & $(38,451,639)$ & 4,347 & 64 & (225) & $(979,205)$ \\
\hline $25-49.9$ & 19,982 & 18,522 & 233 & (881) & $(16,316,697)$ & 1,460 & 102 & (141) & $(206,205)$ \\
\hline $50-99.9$ & 9,220 & 8,381 & 305 & (599) & $(5,024,159)$ & 839 & 116 & 993 & 833,204 \\
\hline $100-249$ & 5,028 & 4,468 & 518 & $(2,167)$ & $(9,681,262)$ & 560 & 127 & 1,734 & 970,878 \\
\hline $250-499$ & 1,761 & 1,494 & 389 & $(2,615)$ & $(3,906,138)$ & 267 & 70 & 17,703 & $4,726,621$ \\
\hline $500-1000$ & 954 & 796 & 347 & $(2,888)$ & $(2,299,007)$ & 158 & 54 & 9,523 & $1,504,609$ \\
\hline $1000-2500$ & 645 & 522 & 363 & $(2,081)$ & $(1,086,292)$ & 123 & 40 & 62,800 & $7,724,345$ \\
\hline$>2500$ & 452 & 356 & 343 & $(9,747)$ & $(3,469,978)$ & 96 & 68 & 385,361 & $36,994,620$ \\
\hline Totals & 363,692 & 338,341 & 2,791 & & $(\$ 467,367,165)$ & 25,351 & 657 & & $\$ 51,568,866$ \\
\hline
\end{tabular}

